\title{
The Reason Why US Should Stop Selling Arms to Saudi Arabia
}

\author{
Qi Lu
}

\author{
Suzhou Experimental High School AP Center, Suzhou, Jiangsu, 25000, China \\ Corresponding author's e-mail: angela@cas-harbour.org
}

\begin{abstract}
This essay will be demonstrated and explained from Microeconomics' point of view, especially focus on externality. The author chooses arms trade between US and KSA, a political issue, as the research topic to expound the negative impact that trade caused. Information is mainly from authoritative organization, including CBS News, Washington Post, etc. Writing methods such as employing magisterial reports, statistics, authoritative definitions are used in the following essay to make the entire essay convinced. The purpose of this essay is to suggest to public that negative economic consequence of US arms trade to KSA, and make clear that US cannot really gain benefits from this trade. Conclusion of essay is that arms trade hurts U.S. economy.
\end{abstract}

Keywords: US arms trade, Yemen crisis, externality, economics

\section{INTRODUCTION}

On account of conflicts of two factions: the Abdrabbuh Mansur Hadi led Yemeni government and the Houthi armed movement, Yemen began its civil war in 2015. As a neighbor of Yemen, Saudi Arabia involves in this war unavoidably. US, as the supporter of KSA, are selling weapons to KSA in order to scramble dominion with Iran which support Houthi armed movement in Yemen civil war. In the following essay, the author will demonstrated the situation of this trade and expound the economic principle behind this trade, and how it bring negative sideeffect to US domestic economy.

\section{BACKGROUND}

"Indiscriminately killed and injured civilians." is the best description of Saudi Arabia airstrikes in Yemen. On account of conflicts of two factions: the Abdrabbuh Mansur Hadi led Yemeni government and the Houthi armed movement, Yemen began its civil war in 2015. As a neighbor of Yemen, Saudi Arabia involved in this war unavoidably. Until March 2019, according to data from The Washington Post, "about 17,729 civilians were killed by bombing."[9] The atrocities of Saudi Arabia are just about killing innocent civilians, also include event of murdering Turkish journalist Khashoggi, who was continued to criticize the Saudi government from afar, and he had been sharply critical of Saudi Arabia's crown prince, Mohammad bin Salman, and the country's king, Salman of Saudi Arabia. Behind all of things Saudi Arabia had done, there is a surreptitious supporter-United States-and US has ineluctable responsibility of Yemen tragedy, according to information from wbur, "KSA with United Arab Emirates are responsible for the airstrikes, however the U.S. plays an essential role by providing the weapons and standing for them in politically."[8] Despite humanitarian objects, U.S. government under Trump administration still support Saudi Arabia by reasoning that Saudi Arabia can be a gangplank of U.S., which can aggrandize controlling power of U.S. in mid-east in order to counterbalance Iran, which is support Houthi armed movement in Yemen civil war. Ipso facto U.S. Energy Information Administration, U.S. imports 770,000 barriers per day from Saudi Arabia which is the second-largest petroleum source of U.S. imports, however, Iran, consider with antagonism towards U.S, controls several most essential transportation ports of mid-east oil. As a result, this is necessary to U.S. to increase its power over mid-east (U.S. Energy Information Administration 24).Yemen possesses huge importance for both US and Iran, President Trump announced that U.S. can get huge benefits from Saudi Arabia, which is his reason to support, though the situation is opposite.

\section{THE EXTERNALITIES IN THE ARMS SALES}

From the point of view of economics, "Externalities exist when people's or organization's action impact another, and they can be both positive and negative. According to the information from Investopedia, there is definitely some kind of externalities exist in the arms trade between US and KSA.” It is negative externalities, which have bad impact to the whole economy of US. In the following essay, the impact of this kind of externalities will be pointed, and reasonable solution will be provided.

After May 20, 2017, U.S. President Trump and Saudi Arabia's Salman signed a series of letters of intent for the Kingdom of Saudi Arabia to purchase arms from the United States totaling US $\$ 110$ billion immediately, and $\$ 350$ billion over 10 years, a long time arms trade was 
progressing between US and KSA. Until 2018 September, "The U.S.government sold $\$ 55.6$ billion of arms around the world and ended Sept. 30 in the fiscal year, this deal is up $33 \%$ from the last fiscal year, according to the information from CBS NEWS." [2] However, such huge arms trade didn't provides enough benefits to cover the costs. Using grenades as an example, since they are top 3 exports that US provides to KSA from the information of US Trade Numbers.

TOP EXPORTS
\begin{tabular}{llr} 
Rank & Commodity & 2019 \\
\hline 1 & Motor vehicles for transporting people & $\$ 1.52 \mathrm{~B}$ \\
\hline 2 & Bombs, grenades, cartridges, parts & $\$ 1.47 \mathrm{~B}$ \\
\hline 3 & Civilian aircraft, parts & $\$ 1.24 \mathrm{~B}$ \\
\hline 4 & Defense-related aircraft, parts & $\$ 1.15 \mathrm{~B}$ \\
\hline 5 & Aircraft engines, engine parts & $\$ 347.45 \mathrm{M}$ \\
\hline 6 & Value added to a returned import & $\$ 287.54 \mathrm{M}$ \\
\hline 7 & Misc. chemical reaction initiators, accelerators & $\$ 286.21 \mathrm{M}$ \\
\hline 8 & Medical instruments for surgeons, dentists, vets & $\$ 271.24 \mathrm{M}$ \\
\hline 9 & Taps, cocks and valves for pipes, tanks & $\$ 218.6 \mathrm{M}$ \\
\hline 10 & Pumps for dispensing liquids & $\$ 185.79 \mathrm{M}$ \\
\hline
\end{tabular}

Figure 1. US top exports

"In the arms market, a rocket-propelled grenade (RPG) launcher cost $\$ 900$ and price of a grenade was around $\$ 100$, according to the information from THE CHRISTIAN SCIENCE."[1] This 100 dollar is the marginal private cost (MPC) of one grenade, which means the cost of an additional unit of output of a good experienced by an individual firm. However, it is not the total costs that one grenade covered. There is a hard, white crystalline solid called RDX, which is the key that making a grenade exploded. After explosion, RDX will release huge amount of pollutions which worsen the global warming. According the definition from Business Dictionary: "Marginal external cost (MEC) is changing in the total cost subjected by households or business, due to the production of an additional unit of the good or service."[4] In this case, these pollutions are MEC, and it is unpractical to calculate the costs of these pollution, so we can assume MEC is unlimited big.

As the information claims from economics. fundamental finance: "When an individual does not pay the full cost of his decision, a negative externality exist. If a good has a negative externality, social cost will greater than the consumer cost."[7] Compared to the data above and the equation: "MPC + MEC = MSC", MSC is bigger than MPC because of unlimited MEC of the pollutions. As a result, it it is easy to define that there are negative externalities.

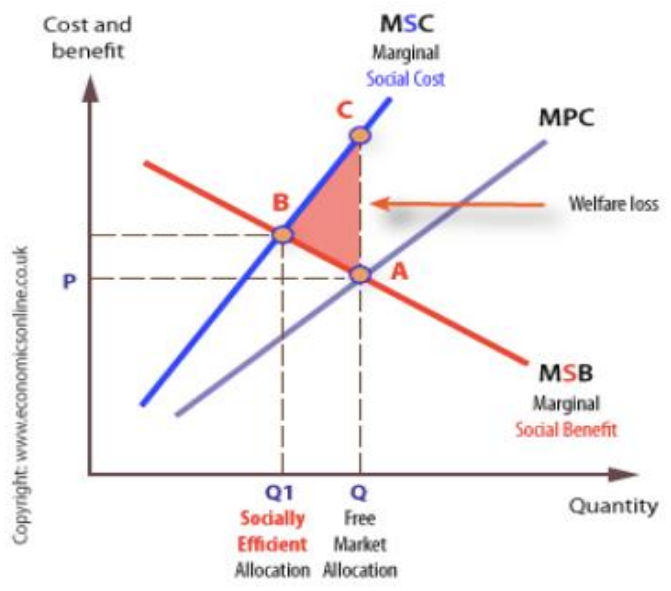

Figure 2. Net welfare loss

As fig. 2 shows, when MSC is bigger than MPC, welfare loss (deadweight loss) will exists, which means the lost welfare as a result of too much or too little production and consumption of a good or resource. The reason of this situation is the market failure, in other words, economy did not allocate resource effectively. As the picture shows, the prices' shifting from A to B means the price increases, and quantity of demand decreases. Under this situation, consumers in domestic US need to spend more money to buy these stuffs, not only grenades, but all exports that US provides to KSA.

Market-based solutions can try to manipulate market forces to reduce this negative externalities, by exploiting the price mechanism, such as extend property rights, or taxes.

First situation, government uses property rights. According to ECONOMICS ONLINE: "When one party build a property right, externalities will exist in the bargaining process."'6] By employing this method, third parties can negotiate with the individuals or organizations who caused these externalities. However, property rights are hard to be established in case of US arms sales, since it includes air and lives which are unpractical to take into account.

Second, government employs taxes. Corrective taxes also know as Pigovian Taxes. As information from Boundless Economics claims: "Social cost of an activity is higher than private cost of that activity when negative externalities exist. In that case, inefficiency of market appear and lead overproduction of the good. Extremely high taxes decline the motivation of production of the good. As the figure shows, a tax shifts the marginal private cost cost curve up. Thus, producers change output to reach the sociallyoptimum level."[3] The Pigovian taxes limit the behavior of individuals or organizations to achieve the goal of reduce negative externalities. 


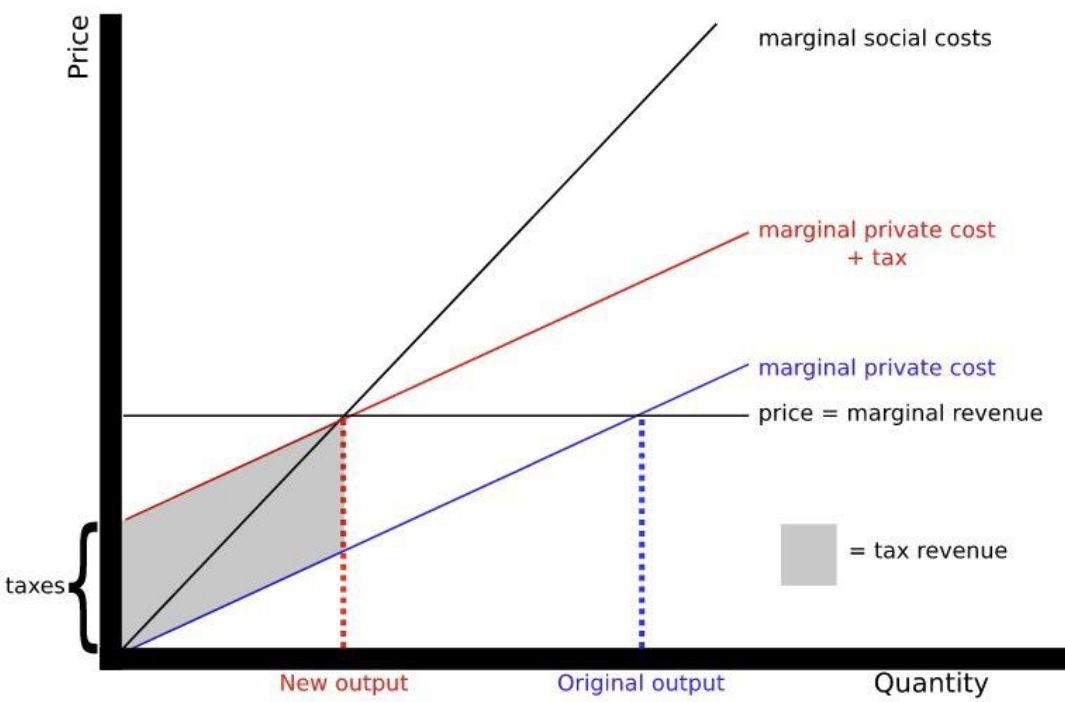

Corrective Tax: A tax shifts the marginal private cost curve up by the amount of the tax. This gives producers an incentive to reduce output to the socially optimum level.

Figure 3. Corrective Tax

In addition, government also can use command-andcontrol policies by creating a Quota to regulate behavior directly. In a quota system, the negative externality is capped at a certain amount.

\section{NEGATIVE EFFECTS ON U.S. BROUGHT BY IMPORTING WEAPONS}

At first, U.S. arm exports provide a short-term benefit to the economy of U.S, about a few billion dollar per year. But if we take all major factors in account, including the cost of taxpayer subsidies for arms exports, the impact of industrial offset programs, the role of arms transfers in fostering regional arms races that can result in additional U.S. defense expenditures, and the opportunity costs for the U.S. and international economies that result from promoting weapons exports instead of commercial activities, promoting arms exports results in a long-term net cost to the U.S. economy. I identified several specific effects of U.S. weapons exports:

First, the hidden taxpayers subsidies. "Hidden taxpayers subsidies is a kind of hidden cost that not include in the purchase price of an good. Instances can be costs for maintain, supplies or upgrades, according to Business Dictionary."[5] Benefits of arms export routinely becloud people that make them neglect potentially cost of this action. Hidden taxpayers subsidies, that are usually collected by government, are among the major costs of weapons export.

Without the help of the U.S., taxpayers and weapons from U.S could not have made it so far around the world. U.S major weapons systems dominates the "top end" of the global weapons market, however, because of technologies and materials of these weapons are often rare and expensive, many poor countries could not afford these utterly. In order to maintain and expand its "weapon market", U.S. government pursues several ways to make sure that poor countries or organization can afford weapons. "The Clinton administration asked for $\$ 6.5$ billion totally in the military aid, including underwrite foreign purchase of U.S. arms ( $\$ 3.4$ billion); security assistance ( $\$ 2.4$ billion); counternarcotics training and equipment ( $\$ 295$ billion); international military education and training (\$52 billion).”[12] The result of paying billions taxpayers's dollars every year to support arms export does not make U.S. more wealthy. In the opposite way, the United States military has had to face troops previously trained by its own military or supplied with U.S. weaponry in Panama, Iraq, Somalia, Haiti, and now in Saudi Arabia. Due to the advanced capabilities these militaries have acquired from past U.S. trading and sales, the U.S. had to invest much more money, which is more than its benefits from exporting arms, and manpower in these conflicts than would have otherwise been needed.

Second, minimal Employment Impacts. A vigorous program of arms transfer restraint would displace less than $0.1 \%$ of the nation's working population. These job losses could be offset by shifting funding from arms export subsidies into domestic investments in areas such as housing, education, and health care, which would produce one and one-half to two times as many jobs per billion dollars spent. In case of exporting arms to Saudi Arabia, Donald Trump, president of U.S, has repeatedly touted a 110 billion dollar exported arms deal he negotiated with Saudi Arabia. He has also touted "500,000" jobs for US citizens through the order. "An internal document shows that only fewer than one thousand jobs in U.S. will be created by the defense contractor, with cost of $\$ 28$ billion 
of goods. However, this deal could provide about 18,000 jobs in KSA. Even if Trump's 110 billion arms deal is true, U.S. still need to put ten of thousand workers to produce goods, according to WASHINGTON [10] and BUSINESS INSIDER.’[11]

\section{CONCLUSION}

To sum up, US arms sales to KSA is inexpedient, and this action is harmful for domestic civilians of US and these world. Stopping arms trade is just like killing two birds with one stone, it not only decrease the rate of death that caused by US weapons in Yemen conflict, but also protect US domestic economy. No matter from point of view of economics or humanism, US government should consider to cut down this action.

However, one important reason US cannot waive the trade to KSA is that if US stop supporting KSA, Houthi will take dominion in Yemen soon. In other words, Iran takes control over Yemen. If this happens, US will loss control over the Mid-East. Thus, it is essential to find a suitable method that do not need to support international war, and take control over Mid-East as well.

\section{ACKNOWLEDGMENT}

First and foremost, I would like to show my deepest gratitude to my teachers and professors in my university, who have provided me with valuable guidance in every stage of the writing of this thesis. Further, I would like to thank all my friends and roommates for their encouragement and support. Without all their enlightening instruction and impressive kindness, I could not have completed my thesis.

\section{REFERENCES}

[1] B. Nicholas. "As Syria unravels, prices soar for guns, grenades, and RPGs". csmonitor.com. THE CHRISTIAN SCIENCE MONITOR. January 92012. Web. March 32020

[2] I. IRINA. "Saudi Arabia is America's No. 1 weapons customer". cbsnews.com. CBS NEWS. Oct 122018. Web. March 32020.

[3] lumen. "Government Policy Options". lumenlearning.com. lumen. Web. March 192020.

[4] Business Dictionary. "Marginal External Cost". businessdictionary.com. Business Dictionary. Web. March 32020.
[5] Business Dictionary. "Hidden taxpayers subsidies". businessdictionary.com. Business Dictionary. Web. March 32020.

[6] ECONOMICS ONLINE. "Negative Externalities".economicsonline.co.uk. ECONOMICS ONLINE. Web. March 32020.

[7] Economics fundamental finance. "Negative Externality". economics.fundamentalfinance.com. economics. Fundamental finance. Web. March 32020.

[8] O. Peter; R. Samantha. "Saudi Arabia Used U.S. Weapons To Target Civilians In Yemen, Human Rights Organization Finds". wbur.org. Here \& Now. March 8 2019. Web. August 52019.

[9] R. Sudarsan. "Airstrike by Saudi-led coalition said to hit near Yemeni hospital, killing 8, including 5 children". washingtonpost.com. The Washington Post. March 27 2019. Web. August 52019.

[10] R. Anna. "U.S. Exports Arms to the World". fas.org. Web. August 72019.

[11] S. Mike. "Defense firms say Trump's Saudi arms deal will create 500 American jobs, while Trump claimed as many as 500,000". businessinsider.com. BUSINESS INSIDER. October 30 2018. Web. August 72019.

[12] USTradeNumber, "SAUDI ARABIA". ustradenumbers.com. USTradeNumbers. Web. March 32020. 